\title{
ANALYSIS OF BUSINESS FEASIBILITY OF BANANA CHIPS
}

\author{
Ruswaji $^{\left.a^{*}\right)}$, Puguh Cahyono ${ }^{a)}$ \\ ${ }^{a)}$ Lamongan Islamic University, Lamongan, Indonesia \\ ${ }^{*}$ Corresponding Author: ruswaji.1965@unisla.ac.id
}

Article history: received 20 August 2020; revised 29 August 2020; accepted 20 September 2020

\begin{abstract}
In this study, the method used is the Net Present Value (NPV) method, Internal Rate of Return (IRR), Payback Period (PP) and Break Event Point (BEP). The results of the study show that the net present value (NPV) is Rp. 31,024,617, - and is feasible because the NPV> 0, the Internal Rate of Return (IRR) of $8.25 \%$ is feasible because it is greater than the deposit interest value applicable to for the bank at this time, the Payback Period (PP) of 2 months is feasible because it is still smaller than the investment period, and the Break Event Point (BEP) of Rp.44,828,693 is feasible because the business is not profitable and does not lose if it earns income. amounting to Rp. 44,828,693, - The banana chip entrepreneurs still maintain the drying of banana chips by using solar energy, because the considerations of raw material prices and production and marketing costs are very sensitive to affect sales and profits.
\end{abstract}

Keywords: feasibility analysis, net present value, internal rate of return, payback period, break event point

\section{INTRODUCTION}

Batu City is a tourist destination for domestic and foreign tourists, because it has a variety of natural charms that have been well managed. The development of tourist objects is increasingly rapid, making the entrepreneurs of souvenirs typical of Batu City growing. This is also felt by the banana chip entrepreneur, who is experiencing very rapid development. In fact, according to data from Desperindag Kota Batu, in 2019 one of the mainstay products that has the potential is banana chips.

Agro-industry is a business to increase the efficiency of the agricultural sector to become a very productive activity through the process of agricultural modernization. Modernization in the industrial sector on a national scale can increase the value added revenue so that export revenues will be greater (Saragih [1]). Banana is one of the agricultural commodities that are very beneficial to human health because of its nutrients (Sonawane [2]), is a staple food in Uganda (Alex [3]), is one of most important food crops in the world (Adeyanju [4]) and functionally according to $\mathrm{Oi}$ [5] it will be optimal benefits, when it is processed for example into banana flour. Bananas can also be made a variety of processed foods, including banana chips. Banana chips is one of traditional foods favored by people in Indonesia. This business has a backward linkage with agri-cultural sector because it uses raw materials from this sector ie bananas. The implication, development of banana chips business will have an impact on development of banana farming due to increasing need of raw materials. Banana chips business is generally a small-scale business, but has an important role in Indonesian economy. According to Tambunan [6] (2013), small business is a largest part of existing business in
Indonesia and contributes significantly to job creation, and poverty reduction.

Banana chips are snack products made from sliced bananas and fried, with or without permitted food additives (SNI 01-4315-1996) (Haryanto [7]). bananas contain high enough nutrition, low cholesterol and high vitamin B6 and vitamin $\mathrm{C}$. The largest nutrients in ripe bananas are 373 milligrams of potassium per 100 grams of bananas, 250-335 grams of vitamin A per 100 grams of bananas and 125 milligrams of chlorine per 100 grams of bananas [8]. Bananas are also a source of carbohydrates, vitamins A and $\mathrm{C}$, and minerals. The largest carbohydrate component in bananas is starch in the pulp, and will be converted into sucrose, glucose and fructose when the banana is ripe (1520\%) (Dame [9]).

However, the increasing market demand made banana chip entrepreneurs trying to increase their sales turnover [10]. However, it is increasingly difficult for entrepreneurs to increase their productivity, this is because the technology used to produce banana chips is still simple. So that it cannot meet the very high market needs. The problem is the drying process of banana chips, because during the dry season the sun is very bright [11]. However, if the rainy season, it is difficult to do the drying. Because if it is dried in the sun for two days, it will reduce the quality of the banana chips. In fact, it will make the product become exposed to mold and not suitable for further processing.

To maintain the quality of the banana chips, it can be done by drying. With drying, banana can be stored longer [12]. The principle of drying banana is an effort to evaporate water because there is a difference in the water vapor content between the air and the dried material. Salt has a less water vapor content than dried material. One of the factors that can accelerate drying is wind or flowing air. . With the presence of air flow, saturated air can be replaced with dry air so that 
the drying process continues. Drying can be done in two ways, namely natural drying and mechanical drying.

Drying banana chips with a mechanical dryer can guarantee better quality than natural drying. Basically a mechanical dryer was created so that drying can be done at any time. In addition, it is hoped that this tool can speed up the drying time and with good quality and quantity of results. Processing of banana chips using traditional drying methods. done by drying in the sun. In the rainy season, the traditional way of processing banana chips produces less good chips because they are less bright and less attractive, namely brownish. Good banana color is brownish yellow. However, drying naturally requires a relatively small cost, but requires a longer time than mechanical drying [13].

\section{RESEARCH METHODS}

The method used is a purposive descriptive method [14]. The purposive method is a method used to deliberately determine the location of research based on specific objectives (Arikunto [15]). collection of data needed for research. The data collected in the form of primary data and secondary data. Primary data is data obtained from the first source either from individuals such as the results of interviews or the results of filling out questionnaires conducted by drying machine experts. Secondary data is primary data that has been further processed and has been presented by other parties, for example in the form of tables or in the form of diagrams. At the data collection stage, the data collected came from four alternative banana chips drying machines, namely using solar energy, electrical energy, waste briquette fuel and LPG fuel. Of the four alternatives, four variables were taken, namely, machine specifications, machine work methods, machine capacity and costs required for operation. The data information was obtained by observing and studying the literature. After collecting the data, then analyzing 4 (four) variables is carried out, namely, machine specifications, machine work methods, machine capacity and costs required for the initial investment. From the four variables analyzed earlier, the best alternative to the banana chip drying machine design is the Binary Dominance Matrix method.

After obtaining the best alternative design for the banana chip drying machine, the next step is to conduct an Engineering Economy analysis. In this study, the method used is the Net Present Value (NPV) method, Internal Rate of Return (IRR), Payback Period (PP) and Break Event Point (BEP). So that after the Engineering Economy analysis is carried out, it will produce a decision, whether the dryer is feasible to run or not.

\section{RESULTS AND DISCUSSION}

The results of the business activities of the respondents who were the samples of this research data were taken in the last 3 (three) years, starting from 2017 to 2019, which includes sales results, operating costs and profits or profits which are detailed as follows table 1
Table 1. Result of Sales of Banana Chips 2017 s.d 2019

\begin{tabular}{|c|c|c|c|}
\hline Year & amount (Rp) & Average per month (Rp) & Growth \\
\hline 2017 & 1.373 .380 .000 & 114.549 .800 & - \\
\hline 2018 & 1.648 .056 .000 & 137.338 .000 & $19,89 \%$ \\
\hline 2019 & 1.977 .667 .200 & 164.805 .600 & $20,00 \%$ \\
\hline
\end{tabular}

Source: Primary data (processed), 2020

Based on the table 1. above shows that the turnover or sales of banana chips in Batu City continued to increase in 2017 amounting to IDR $1,373,380,000$ or an average of IDR $114,549,800$ per month increased to IDR $1,648,056,000$ in 2018 or an average of IDR $1,373,380,000$ per month. IDR $137,338,000$ or an increase of $19.89 \%$. Meanwhile, in 2019 it increased to IDR $1,977,667,200$ or an average of IDR $164,805,600$ per month or an increase of $20.00 \%$ from 2018.

Table 2. Banana Chips Operating Costs 2017 s.d 2019

\begin{tabular}{|c|c|c|c|}
\hline Year & amount (Rp) & $\begin{array}{c}\text { Average per month } \\
(\mathrm{Rp})\end{array}$ & Growth \\
\hline 2017 & 168.107 .600 & 14.008 .967 & - \\
\hline 2018 & 201.729 .120 & 16.810 .760 & $19,99 \%$ \\
\hline 2019 & 242.074 .944 & 20.172 .912 & $20,00 \%$ \\
\hline
\end{tabular}

Source: Primary data (processed), 2020

Based on the table 2. above, it shows that the operational costs of banana chips in Batu City continue to experience a fairly good increase in efficiency in 2017 amounting to IDR $168,107,600$ or an average of IDR $14,008,967$, up to IDR $201,729,120$ in 2018 or on average. amounting to Rp. $16,810,760$ or an increase of $19.99 \%$. Whereas in 2019 it increased again to IDR 242,074,944 or an average per month of IDR 20,172,912 or an increase of $20.00 \%$ from 2018.

Table 3. Fixed Costs and Variable Costs of Banana Chips 2017 s.d 2019

\begin{tabular}{|c|c|c|c|}
\hline Year & $\begin{array}{c}\text { Fixed cost } \\
(\mathrm{Rp})\end{array}$ & $\begin{array}{c}\text { Variable Costs } \\
(\mathrm{Rp})\end{array}$ & $\begin{array}{c}\text { Total cost } \\
(\mathrm{Rp})\end{array}$ \\
\hline 2017 & 33.621 .520 & 134.486 .080 & 168.107 .600 \\
\hline 2018 & 40.345 .824 & 161.383 .296 & 201.729 .120 \\
\hline 2019 & 48.414 .989 & 193.659 .955 & 242.074 .944 \\
\hline amount & 122.382 .333 & 489.529 .331 & 611.911 .664 \\
\hline
\end{tabular}

Source: Primary data (processed), 2020

Based on the table 3. above, it shows that the fixed costs and variable costs of banana chips in Batu City have increased the efficiency which is quite good so that it will affect the increase in profits obtained by banana chip entrepreneurs in Batu City.

Based on the table 4. above, it shows that the fixed costs and variable costs of banana chips in Batu City have increased the efficiency which is quite good so that it will affect the increase in profits obtained by banana chip entrepreneurs in Batu City. 
Table 4. Banana Chips Business Profits / Profits 2017 s.d 2019

\begin{tabular}{|c|c|c|c|}
\hline Year & $\begin{array}{c}\text { Fixed cost } \\
(\mathrm{Rp})\end{array}$ & $\begin{array}{c}\text { Variable Costs } \\
(\mathrm{Rp})\end{array}$ & Growth \\
\hline 2017 & 1.205 .272 .400 & 100.439 .367 & - \\
\hline 2018 & 1.446 .326 .880 & 120.527 .240 & $19,99 \%$ \\
\hline 2019 & 1.735 .592 .256 & 144.632 .688 & $20,00 \%$ \\
\hline
\end{tabular}

Source: Primary data (processed) 2020

Table 5. Banana Chips Business Profits / Profits 2017 s.d 2019

\begin{tabular}{|c|c|c|c|}
\hline Year & amount (Rp) & Average per month (Rp) & Growth \\
\hline 2017 & 1.205 .272 .400 & 100.439 .367 & - \\
\hline 2018 & 1.446 .326 .880 & 120.527 .240 & $19,99 \%$ \\
\hline 2019 & 1.735 .592 .256 & 144.632 .688 & $20,00 \%$ \\
\hline
\end{tabular}

Source: Primary data (processed) 2020

Based on the table above, it shows that the profit or profit of the banana chips business in Batu City continues to increase quite well in 2017 amounting to IDR 1,205,272,400 or an average of IDR $100,439,367$ per month to IDR $1,446,326,880$ in 2018 or an average of IDR 120,527,240 or an increase of $19.99 \%$. Whereas in 2019 it increased again to IDR $1,735,592,256$ or an average per month of IDR $144,632,688$ or an increase of $20.00 \%$ from 2019.

\section{Net Present Value (NPV) Analysis}

Net Present Value (NPV) is a method used by comparing the present value of net cash inflows with the present value of costs incurred.

Table 6. The result of the NPV

\begin{tabular}{|c|c|c|c|}
\hline Year & $\begin{array}{c}\text { Average effort } \\
\text { per month }\end{array}$ & $\begin{array}{c}\text { Discount Factor } \\
(\mathrm{r}=6 \%)\end{array}$ & $\begin{array}{c}\text { Present Value } \\
(\mathrm{NPV})\end{array}$ \\
\hline 0 & 337.549 .800 & 1 & $(337.549 .800)$ \\
\hline 1 & 174.448 .333 & 0,9434 & 107.970 .126 \\
\hline 2 & 137.338 .000 & 0,8900 & 122.230 .331 \\
\hline 3 & 164.805 .600 & 0,8396 & 138.373 .960 \\
\hline NPV & & & $\mathbf{3 1 . 0 2 4 . 6 1 7}$ \\
\hline
\end{tabular}

The result of the NPV calculation is positive (NPV> 0 ), which is IDR $31,024,617$, meaning that the business is feasible.

\section{Internal Rate Of Return (IRR) Analysis}

Internal Rate of Return (IRR) is a method used to calculate an interest rate which equates the present value of all incoming cash flows and outflows. Interpolation method is used to find the same interest rate.

Table 7. Internal Rate Of Return

\begin{tabular}{|c|c|c|c|c|c|}
\hline Year & $\begin{array}{c}\text { Average } \\
\text { effort per } \\
\text { month }\end{array}$ & $\begin{array}{c}\text { Discount } \\
\text { Factor } \\
(\mathrm{r}=6 \%)\end{array}$ & $\begin{array}{c}\text { Discount } \\
\text { Factor } \\
(\mathrm{r}=9 \%)\end{array}$ & $\begin{array}{c}\text { Present } \\
\text { Value } \\
(\mathrm{r}=6 \%)\end{array}$ & $\begin{array}{c}\text { Present } \\
\text { Value } \\
(\mathrm{r}=9 \%)\end{array}$ \\
\hline 0 & 337.549 .800 & 1 & 1 & $\begin{array}{c}337.549 .800 \\
)\end{array}$ & $\begin{array}{c}337.549 .80 \\
0)\end{array}$ \\
\hline 1 & 114.448 .333 & 0,9434 & 0,9174 & 107.970 .126 & 104.998 .471 \\
\hline 2 & 137.338 .000 & 0,8900 & 0,8417 & 122.230 .331 & 115.594 .647 \\
\hline 3 & 164.805 .600 & 0,8396 & 0,7722 & 138.373 .960 & 127.260 .162 \\
\hline NPV & & & & $\mathbf{3 1 . 0 2 4 . 6 1 7}$ & $\mathbf{1 0 . 3 0 3 . 4 8 0}$ \\
\hline
\end{tabular}

$$
I R R=r_{p o s}+\frac{N P V_{\text {pos }}\left(r_{\text {neg }}-r_{\text {pos }}\right)}{N P V_{\text {pos }}+N P V_{\text {neg }}}
$$

So the results of the IRR calculation are as follows:

$$
I R R=6 \%+\frac{40.794 .111(9-6)}{31.024 .617+10.303 .480}
$$

$$
I R R=8,25 \%
$$

The IRR value is $8.25 \%$ greater than the current bank deposit interest rate, so the business is feasible.

\section{Payback Period (PP)}

Payback Period (PP) is used to determine how long the capital is invested in a return effort. The best PP alternative is the fastest in returning the capital. There are two assumptions used to calculate PP, namely if a business has the same cash flows and if the business does not have the same cash flows.

Table 7. Payback Period

\begin{tabular}{|c|c|}
\hline Description & Joint Venture $(\mathrm{Rp})$ \\
\hline Capital & 337.549 .800 \\
\hline Cash Flow & 1.666 .367 .733 \\
\hline Time of Effort & 3 years \\
\hline
\end{tabular}

$$
\begin{aligned}
\text { Then PP } & =\frac{337,549,800}{1,666,367,733} \\
\text { Then PP } & =0,20
\end{aligned}
$$

Based on the results of these calculations PP chips business for 2 months.

\section{Break Event Points (BEP)}

The break-even point or Break Event Point (BEP) is a value which shows that a business does not experience profits or losses. BEP is a critical point of an effort. If the business owner wants a profit, his production and income must be above the BEP.

In general, the formula used is as follows:

$$
\text { Income } \mathrm{BEP}=\frac{\mathrm{FC}}{1-\frac{V C}{T R}}
$$

From the research results obtained the following data

Fixed Costs $($ Fixed Cost $)=40,794,111$

Variable cost $($ Variable Cost $)=163,176,444$

Total Revenue $(\mathrm{TR})=1,666,367,733$ 
Then the BEP:

$$
\text { Income } \mathrm{BEP}=\frac{\mathrm{FC}}{1-\frac{V C}{T R}}
$$

Income BEP $=\frac{40,794,111}{1-\frac{163,176,444}{1,666,367,733}}$

Income BEP $=44,828,693$

Income BEP of Rp. 44,828,693 indicates that the business is not profitable and does not lose if it earns an income of Rp.44,828,693.

\section{CONCLUSION}

Based on the results of research on the banana chip business in Batu City, it can be concluded that the business activity is feasible to be cultivated and developed because it produces an NPV (Net Present Value) of IDR 31,024,617, Internal Rate Of Return (IRR) of $8.25 \%$; Payback Period (PP) for 2 months and Break Event Point (BEP) of IDR $44,828,693$. This is because the Batu City Government through the Integrated Business Service Center (PLUT) continues to contribute to providing guidance and assistance to all MSMEs - MSMEs, one of which is the banana chip business group which is managed in accordance with good Appropriate Technology Standards. Although most of the businessmen still do it manually, and the drying process still uses sunlight because of the consideration of raw material prices, production costs and marketing which greatly affect the profit.

Based on the research results and conclusions drawn, the authors have suggestions: The local government agency offices should pay more attention to the functions and benefits of the application of appropriate technology programs ranging from banana slicing machines to alternative drying machines that really provide high economic value for banana chip entrepreneurs, so that the growth in the number of banana chip business members is more significant and the end result is The increase in income of the banana chip entrepreneurs has increased. For the next researcher, it is expected that the addition of other variables is used so that the results are more valid and reliable

\section{REFERENCES}

[1] Saragih B. 2008 Kumpulan Pemikiran Agribisnis Berbasis Peternakan. USESE Fondation dan Pusat Studi Pembangunan. IPB Bogor.

[2] Sonawane, S.P.; Sharma, G.P. and Pandya, A.C. 2011. Design and development of power operated banana slicer for small scale food processing industries. Res. Agr. Eng.Vol. 57, 2011, No. 4: 144-152.
[3] Alex, A., Jeremia, M., George, T. and Anna, S. 2015. Assessment of innovative market access options for banana value chain in Uganda. Journal of Development and Agricultural Economics. Vol. 7(10), pp. 323-331, October, 2015. DOI: 10.5897/JDAE2015.0644. ISSN 2006-9774

[4] Adeyanju, J.A., Olajide, J.O., and Adedeji, A.A. 2016. Optimisation of Deep-Fat Frying of Plantain Chips (Ipekere) using Response Surface Methodology. Journal of Food \& Technology. 7:5.

[5] Oi, R.K.; Santanac, J.C.C.; Tambourgi, E.B.; Júnior, M. 2013. Feasibility Study for Production of Green Banana Flour in a Spray Dryer. Chemmical Engineering Transactions Vol 32, 2013. ISSN 1974-9791

[6] Tambunan, T. 2013. Reformasi Subsidi Bahan Bakar Fosim dan Usaha Kecil Menengah (UKM): Dampak dan Alternatif Tanggapan. Pusat Studi Industri, UKM dan Persaingan Bisnis, USAKTI. Briefing note. Global Subsidies Initiative. International Institute for Sustainable Development.

[7] Haryanto, D., Nawansih, O., \& Nurainy, F. 2013. Penyusunan Draft Standard Operating Procedure (SOP) Pengolahan Keripik Pisang (Studi Kasus Di Salah Satu Industri Rumah Tangga Keripik Pisang Bandar Lampung). Jurnal Teknologi Industri Dan Hasil Pertanian, 18(2), 132-143.

[9] Dame Yanti Ambarita, M., Sartini Bayu, E., \& Setiado, H. 2015. Identifikasi Karakter Morfologis Pisang (Musa spp) di Kabupaten Deli Serdang. Jurnal Agroekoteknologi, 4(1), 1911-1924.

[10] Maria, 2010. "Net Present Value With A Spreadsheet", Journal of Defense Resources Management.

[11] Mariam A. Basra Pasau dkk, 2015. Analisis Pendapatan dan Kelayakan Usaha Keripik Ubikayu pada Industri Pundi Mas di Kota Palu, Jurnal Agrotekbis 3(3) : 402 - 408. Fakultas Pertanian. Taduloko. Palu.

[12] Sumiyati. 2013. Analisis Kelayakan Keripik Pisang Di Kecamatan Gorontalo.

[13] Anwar, H.C., Lanya, B., Haryanto, A., Tamrin, 2012, Rancang Bangun Alat Pengering Energi Surya Dengan Kolektor Keping Datar, Jurnal Teknik Pertanian Lampung Vol. 1, No. 1,Oktober 2012 : 2936

[14] Ibnu Sajari, Elfiana, M. 2017. Analisis Kelayakan Usaha Keripik Pada UD. Mawar di Gampong Batee Ie Liek Kecamatan Samalanga Kabupaten Bireuen. Jurnal S. Pertanian, 1(2), 116-124.

[15] Arikunto, S. 2006. Prosedur Penelitian Suatu Pendekatan Praktik. Jakarta: PT. Rineka Cipta. 